\title{
PENGARUH HUBUNGAN INTERPERSONAL, LINGKUNGAN KERJA, DAN KECERDASAN EMOSIONAL TERHADAP KINERJA PEGAWAI PADA KANTOR KOMISI PEMILIHAN UMUM DAERAH (KPUD) KABUPATEN PARIGI MOUTONG
}

\author{
ABD RAHMAN \\ (Dosen Fakultas Ekonomi Universitas Alkhairaat) \\ Hendra Siswanto \\ (Mahasiswa Program Studi Manajemen Fakultas Ekonomi Universitas Alkhairaat)
}

\begin{abstract}
ABSTRAK
Tujuan penelitian ini adalah untuk mengetahui dan menganalisis pengaruh hubungan interpersonal, lingkungan kerja dan kecerdasan emosional terhadap kinerja pegawai Kantor Komisi Pemilihan Umum Daerah (KPUD) Kabupaten Parigi Moutong. Populasi dalam penelitian ini adalah seluruh pegawai yang bekerja dilingkungan Kantor KPUD Kabupaten Parigi Moutong sebanyak 59 orang. Untuk mencapai tujuan tersebut ditarik sampel sebanyak 38 orang responden dengan metode Proporsional Random Sampling, dan alat analisis yang digunakan adalah regresi linear berganda.

Hasil penelitian ini menyimpulkan bahwa ketiga variabel bebas yakni hubungan interpersonal, lingkungan kerja dan kecerdasan emosional secara serempak berpengaruh positif dan signifikan terhadap kinerja pegawai Kantor Komisi Pemilihan Umum Daerah (KPUD) Kabupaten Parigi Moutong, serta berdasarkan hasil analisis disimpulkan bahwa kedua variabel bebas yakni hubungan interpersonal dan lingkungan kerja secara parsial berpengaruh signifikan terhadap kinerja pegawai Kantor Komisi Pemilihan Umum Daerah (KPUD) Kabupaten Parigi Moutong. Sedangkan salah satu variabel bebas yakni variabel kecerdasan emosional tidak berpengaruh terhadap kinerja pegawai Kantor Komisi Pemilihan Umum Daerah (KPUD) Kabupaten Parigi Moutong.
\end{abstract}

Kata Kunci: Hubungan Interpersonal, Lingkungan Kerja, Kecerdasan Emosional, Kinerja

\section{LATAR BELAKANG}

Derasnya arus globalisasi dan perkembangan Ilmu Pengetahuan dan Tekhnologi yang semakin cepat telah membawa perubahanperubahan dan menciptakan paradigma baru di dalam organisasi. Organisasi tidak hanya sematamata mengejar pencapaian produktifitas yang tinggi saja, tetapi juga lebih memperhatikan kinerja dalam proses pencapaian. Dalam organisasi pemerintah maupun swasta pencapaian tujuan ditetapkan melalui sarana dalam bentuk organisasi yang digerakkan oleh sekelompok orang yang berperan aktif sebagai pelaku dalam mencapai tujuan organisasi, pencapaian itu hanya dimungkinkan karena upaya para pegawai yang terdapat pada organisasi yang disebut sebagai kinerja pegawai.

Kinerja pegawai merupakan salah satu faktor yang memegang peran penting dalam mencapai tujuan instansi pemerintahan maupun tujuan individu pegawai itu sendiri, tidak terkecuali bagi Komisi Pemilihan Umum Daerah (KPUD) Kabupaten Parigi Moutong. Sebagai lembaga pemerintah, KPUD Kabupaten Parigi Moutong dituntut untuk memberikan kinerja yang optimal dalam pelaksanaan pemilihan umum karena tugas dan fungsi KPUD Kabupaten Parigi Moutong menyelenggarakan dan bertanggung jawab atas pemilihan umum atau pemilihan kepala daerah.

Kinerja pegawai merupakan prestasi kerja atau hasil kerja, baik kualitas maupun kuantitas yang dicapai oleh seorang pegawai persatuan periode waktu dalam melaksanakan tugas kerjanya sesuai dengan tanggung jawab yang diberikan kepadanya. Terdapat beberapa faktor yang mempengaruhi kinerja pegawai yaitu faktor pengetahuan, keterampilan, dan kemampuan sangat diperlukan untuk mendukung suatu kinerja. 
Pengetahuan, keterampilan dan kemampuan merupakan kompetensi yang bersifat supervisial, yaitu karakter mendasari seseorang untuk mampu menunjukkan kinerja yang efektif atau superior di dalam pekerjaan dan tugasnya.

Salah satu aspek pribadi yang merupakan kompetensi adalah komunikasi antar pribadi, dengan komunikasi antar pribadi yang baik organisasi dapat memelihara motivasi pegawai dengan memberikan penjelasan kepada pegawai tentang apa yang harus mereka kerjakan dan apa yang dapat dilakukan pegawai untuk meningkatkan kinerjanya. Komunikasi antar pribadi sering juga disebut dengan hubungan interpersonal.

Hubungan interpersonal dapat diartikan sebagai hubungan antar pribadi dengan pribadi yang lain. Hal itu sejalan dengan fitrah manusia selain sebagai makhluk individual juga sebagai makhluk sosial sehingga hubungan interpersonal pasti akan di alami oleh seluruh manusia yang hidup secara normal. Komunikasi yang efektif ditandai dengan hubungan interpersonal yang baik. Ketika pegawai berkomunikasi, pegawai bukan sekedar menyampaikan isi pesan, tetapi pegawai juga menentukan kadar hubungan interpersonalnya. Komunikasi yang baik dapat meningkatkan saling pengertian, kerjasama, dan kepuasan kerja. Pegawai yang mempunyai kompetensi komunikasi yang baik akan mampu memperoleh dan mengembangkan tugas yang diembannya, sehingga tingkat kinerja pegawai menjadi semakin baik. Semakin baik hubungan interpersonal, makin terbuka orang untuk mengungkapkan dirinya makin cermat persepsinya tentang orang lain dan persepsi dirinya, sehingga makin efektif. Oleh sebab itu komunikasi merupakan bagian yang penting dalam kehidupan kerja. Sebaliknya, komunikasi yang tidak baik bisa mempunyai dampak yang buruk terhadap kehidupan organisasi, misalkan konflik antar pegawai.

Menurut pengamatan penulis saat melakukan prasurvey dan pengamatan di kantor KPUD Kabupaten Parigi Moutong, terdapat adanya beberapa faksi atau pengelompokkan. Pengelompokkan terjadi karena adanya perbedaan dari sisi status sosial, pendidikan dan penghasilan. Hal ini sangat berpotensi menganggu hubungan interpersonal pegawai dan kenyamanan kerja dari pegawai lain karena komunikasi individu yang tidak berjalan lancar.
Selanjutnya lingkungan kerja juga merupakan salah satu faktor yang menyebabkan peningkatan kinerja pegawai. Lingkungan kerja merupakan segala sesuatu yang ada disekitar para pekerja yang dapat mempengaruhi dirinya dalam mejalankan tugas-tugas yang dibebankan. Lingkungan kerja fisik dalam suatu organisasi merupakan suatu kondisi pekerjaan untuk memberikan suasana dan situasi kerja pegawai yang nyaman dalam pencapaian tujuan yang diinginkan oleh suatu organisasi. Kondisi kerja yang buruk berpotensi menjadi penyebab menurunnya produktivitas kerja. Jika ruangan kerja tidak nyaman, panas, sirkulasi udara kurang memadai, ruangan kerja terlalu padat, lingkungan kerja kurang bersih, berisik, tentu besar pengaruhnya pada kenyamanan kerja pegawai. Dalam mencapai kenyamanan tempat kerja antara lain dapat dilakukan dengan jalan memelihara prasarana fisik seperti seperti kebersihan yang selalu terjaga, penerangan cahaya yang cukup, ventilasi udara, suara musik dan tata ruang kantor yang nyaman. Pihak manajemen organisasi juga hendaknya mampu mendorong inisiatif dan kreatifitas. Kondisi seperti inilah yang selanjutnya menciptakan antusiasme untuk bersatu dalam organisasi untuk mencapai tujuan organisasi dengan meningkatkan kinerja pegawai.

Selain faktor hubungan interpersonal dan dukungan lingkungan kerja yang baik, faktor yang mempengaruhi kinerja pegawai adalah faktor kecerdasan emosional pegawai itu sendiri. Konsep kecerdasan emosional merupakan fenomena yang masih terbilang baru dalam dunia psikologi industri dan organisasi, akan tetapi penggunaannya dalam dunia kerja saat ini sangat dibutuhkan. Kecerdasan emosional memungkinkan seseorang untuk mengelola emosinya dengan baik, sehingga terekspresikan secara tepat dan efektif, yang pada akhirnya akan membawa orang tersebut mampu bekerja sama dengan lancar menuju sasaran dan tujuan organisasi.

Kecerdasan emosional adalah kemampuan untuk mengenal perasaaan diri sendiri dan orang lain untuk memotivasi diri sendiri dan mengelola emosi dengan baik dalam diri kita dan hubungan kita. Kecerdasan emosional menuntut pemilik perasaan untuk belajar jujur, menghargai perasaan pada diri sendiri dan orang lain, menanggapinya dengan tepat, serta menerapkan secara efektif energi emosi dalam kehidupan sehari-hari. 
Kecerdasan emosional yang baik akan membuat seseorang mampu membuat keputusan yang tegas dan tepat walaupun dalam keadaan tertekan. Kecerdasan emosional juga membuat seseorang dapat menunjukkan integritasnya. Pegawai dengan kecerdasan emosional yang baik mampu berfikir jernih walaupun dalam tekanan, bertindak sesuai etika, berpegang pada prinsip dan memiliki dorongan berprestasi. Kecerdasan emosional berarti menggunakan emosi secara efektif untuk mencapai tujuan dengan tepat, membangun hubungan kerja yang produktif dan meraih keberhasilan di tempat kerja.

Berdasarkan uraian latar belakang diatas, penulis tertarik untuk mengadakan penelitian dengan judul "Pengaruh Hubungan Interpersonal, Lingkungan Kerja, dan Kecerdasan Emosional Terhadap Kinerja Pegawai Kantor Komisi Pemilihan Umum Daerah (KPUD) Kabupaten Parigi Moutong"

Sebagaimana latar belakang yang telah diuraikan sebelumnya, maka permasalahan dalam penelitian ini adalah sebagai berikut:

1. Apakah hubungan interpersonal, lingkungan kerja dan kecerdasan emosional secara serempak berpengaruh terhadap kinerja pegawai Kantor Komisi Pemilihan Umum Daerah (KPUD) Kabupaten Parigi Moutong?

2. Apakah hubungan interpersonal berpengaruh terhadap kinerja pegawai Kantor Komisi Pemilihan Umum Daerah (KPUD) Kabupaten Parigi Moutong?

3. Apakah lingkungan kerja berpengaruh terhadap kinerja pegawai Kantor Komisi Pemilihan Umum Daerah (KPUD) Kabupaten Parigi Moutong?

4. Apakah kecerdasan emosional berpengaruh terhadap kinerja pegawai Kantor Komisi Pemilihan Umum Daerah (KPUD) Kabupaten Parigi Moutong?

\section{KAJIAN PUSTAKA}

\section{Hubungan Interpersonal}

Hubungan interpersonal adalah interaksi antara seseorang dengan orang lain dalam situasi kerja dan dalam organisasi sebagai motivasi untuk bekerjasama secara produktif, sehingga dicapai kepuasan ekonomi, psikologis, dan sosial. (Robbins, 2002; 156).

Menurut Effendy (2008; 9) ada dua pengertian hubungan antar manusia, yaitu hubungan dalam arti luas dan arti sempit. Dalam arti luas hubungan antar manusia adalah
Interkomunikasi yang dilakukan oleh seseorang kepada orang lain dalam segala situasi dan di dalam semua bidang kehidupan, sehingga menimbulkan rasa puas dan bahagia kepada kedua pihak. Pengertian hubungan antar manusia dalam arti sempit adalah Interkomunikasi yang dilakukan oleh seseorang kepada orang lain secara langsung bertatap muka dalam suatu organisasi kerja (work organization) dan dalam berbagai situasi kerja (work situation) dengan tujuan untuk menggugah kegairahan kerja dengan semangat kerjasama yang produktif serta dengan perasaan dan bahagia.

Menurut Robbins (2002; 161) secara umum manfaat yang paling mendasar dengan adanya hubungan antar manusia yang sehat dalam suatu organisasi adalah meningkatkan produktivitas kerja personil organisasi tersebut. Selain itu tujuan hubungan antar manusia dalam organisasi sebenarnya dapat mencegah timbulnya konflik, terutama konflik interpersonal atau konflik antar pribadi pada kantor yang biasanya dapat merugikan terhadap kelangsungan aktivitas organisasi.

Effendy $(2008 ; 12)$ mengemukakan cara mengembangkan hubungan interpersonal, meliputi:

1. Mengasah Kepekaan Empati dan Simpati

Simpati adalah keikutsertaan merasakan perasaan orang lain dan menaruh belas kasihan pada sesama. Empati adalah keadaan mental yang membuat seseorang merasa atau mengidentifikasi dirinya dalam keadaan perasaan atau pikiran yang sama dengan orang atau kelompok orang. Empati dan simpati perlu dirangsang sejak dini agar anak dapat belajar mengenai setiap perasaan, maksud dan motivasi orang lain, yang pada akhirnya kelak ia dapat menangkap perasaan, maksud dan motivasi tersebut secara akurat. Hal ini membawa keakuratan bertindak atau merespons karena anak memiliki informasi yang tepat tentang stimulusnya.

2. Bekerja Sama

Bekerja sama diwujudkan dalam bentuk kegiatan yang dilakukan oleh dua orang karyawan/pegawai atau lebih. Kegiatan tersebut mengacu pada aktivitas menyelesaikan suatu pekerjaan secara bersama-sama, seperti: diskusi kelompok dan kerja kelompok.

3. Berbagi Rasa

Berbagi rasa merupakan salah satu indikator kecerdasan interpersonal yang melibatkan 
kemampuan bersosialisasi dan berinteraksi dengan orang lain. Berbagi rasa dapat dirangsang dengan kegiatan yang mengharuskan pegawai berinteraksi dengan sesamanya. Hal ini dapat dilakukan dengan tugas-tugas yang melibatkan kebersamaan

4. Menjalin Kontak

Kemampuan menjalin kontak menunjukkan kecerdasan interpersonal yang tinggi. Pegawai perlu didorong untuk memiliki keberanian, kemauan untuk menjalin kontak dan membina hubungan baik dengan orangorang baru.

5. Mengorganisasi Teman

Pegawai yang cerdas dalam interpersonal memiliki kemampuan mengorganisasi teman-teman mereka dengan baik. Mereka mampu menempatkan teman-teman sebayanya sesuai peran yang tepat.

6. Menebak Suasana Hati

Seseorang yang cerdas dalam interpersonal memiliki kemampuan menangkap suasana hati orang lain. Melalui ciri-ciri yang sangat halus, mereka mampu menangkap apa yang sedang dirasakan orang lain. Pegawai perlu distimulasi agar memiliki kemampuan ini. Stimulasi yang baik dan tepat akan menumbuhkan kemampuan menangkap suasana hati orang lain secara optimal.

7. Memotivasi Orang Lain

Karyawan/pegawai dengan kecerdasan interpersonal yang kuat pandai memotivasi orang lain, mereka dapat membaca suasana hati dan kesulitan orang lain, lalu memberikan tanggapan yang tepat berupa kata-kata yang membangkitkan hati. Terhadap sesuatu kegiatan, mereka juga tampil sebagai pendorong semangat.

Selanjutnya menurut Effendy (2008; 14), setelah mengemukakan cara mengembangkan hubungan interpersonal di atas, maka yang dapat dijadikan indikator hubungan interpersonal sebagai berikut:

1) Harga menghargai

2) Loyal dan toleran antara satu dengan yang lainnya

3) Sikap terbuka

4) Adanya keakraban.

\section{Lingkungan Kerja}

Lingkungan kerja adalah kehidupan sosial, psikologi, dan fisik dalam perusahaan yang berpengaruh terhadap pekerja dalam melaksanakan tugasnya. Kehidupan manusia tidak terlepas dari berbagai keadaan lingkungan sekitarnya, antara manusia dan lingkungan terdapat hubungan yang sangat erat. Dalam hal ini, manusia akan selalu berusaha untuk beradaptasi dengan berbagai keadaan lingkungan sekitarnya. Demikian pula halnya ketika melakukan pekerjaan, karyawan sebagai manusia tidak dapat dipisahkan dari berbagai keadaan disekitar tempat mereka bekerja, yaitu lingkungan kerja. Selama melakukan pekerjaan, setiap pegawai akan berinteraksi dengan berbagai kondisi yang terdapat dalam lingkungan kerja.

Menurut Nitisemito (2000; 183) lingkungan kerja adalah segala sesuatu yang ada di lingkungan sekitar para pekerja dan yang dapat mempengaruhi dirinya dalam menjalankan tugastugas yang dibebankan kepadanya, misalnya kebersihan, musik, dan lain-lain. Selanjutnya menurut Sedarmayati $(2001 ; 11)$ lingkungan kerja merupakan keseluruhan alat perkakas dan bahan yang dihadapi, lingkungan sekitarnya dimana seseorang bekerja, metode kerjanya, serta pengaturan kerjanya baik sebagai perseorangan maupun sebagai kelompok.

Menurut Sedarmayanti $(2001 ; 21)$ faktorfaktor yang dapat mempengaruhi terbentuknya suatu kondisi lingkungan kerja yang selanjutnya dijadikan indikator lingkungan kerja adalah sebagai berikut:

1) Kondisi ruangan kerja

Ketika ruang kerja tertata dengan baik dan membuat nyaman, bekerja seharian penuh tidak akan menjadi membosankan. Sebab lingkungan sangat mendukung keseimbangan kerja antara bekerja keras dan bersantai di sela-sela waktu kerja.

2) Dekorasi ruangan kerja (Lay Out)

Dekorasi (lay out) ada hubungannya dengan tata warna yang baik, karena itu dekorasi tidak hanya berkaitang dengan hasil ruang kerja saja, tetapi berkaitan juga dengan cara mengatur tata letak, tata warna, perlengkapan, dan lainnya untuk bekerja.

3) Fasilitas dan alat bantu pekerjaan

Segala sesuatu yang yang menyangkut fasilitas dan faktor fisik yang menjadi menjadi kewajiban serta tanggung jawab perusahaan meliputi fasilitas dan alat bantu keamanan dalam bekerja.

4) Keadaan udara

Suhu udara dalam ruangan kerja merupakan salah satu faktor yang harus diperhatikan 
oleh manajemen perusahaan agar karyawan dapat bekerja dengan menggunakan seluruh kemampuan sehinggan menciptakan hasil yang optimal.

5) Ketenangan dalam ruang kerja.

Untuk sebuah pekerjaan membutuhkan konsentrasi, maka suara bising hendaknya dihindarkan dalam ruang kerja.

\section{Kecerdasan Emosional}

Istilah "kecerdasan emosional" pertama kali dilontarkan pada tahun 1990 oleh psikolog Peter Salovey dari Harvard University dan John Mayer dari University of New Hampshire untuk menerangkan kualitas-kualitas emosional yang tampaknya penting bagi keberhasilan.

Menurut Cooper dalam Setyawan (2005; 117), kecerdasan emosi adalah kemampuan merasakan, memahami dan secara efektif menerapkan daya dan kepekaan emosi sebagai sumber energi, informasi, koreksi dan pengaruh yang manusiawi. Kecerdasan emosi menuntut penilikan perasaan untuk belajar mengakui, menghargai perasaan pada diri dan orang lain serta menanggapinya dengan tepat, menerapkan secara efektif energi emosi dalam kehidupan sehari-hari. Dimana kecerdasan emosi juga merupakan kemampuan untuk menggunakan emosi secara efektif untuk mencapai tujuan untuk membangun produktif dan meraih keberhasilan.

Goleman dalam Setyawan (2005; 119) mendefinisikan bahwa kecerdasan emosi adalah suatu kemampuan seseorang yang didalamnya terdiri dari berbagai kemampuan untuk dapat memotivasi diri sendiri, bertahan menghadapi frustasi, mengendalikan impulsive needs atau dorongan hati, tidak melebih-lebihkan kesenangan maupun kesusahan, mampu mengatur reactive needs, menjaga agar bebas stress, tidak melumpuhkan kemampuan berfikir dan kemampuan untuk berempati pada orang lain, serta adanya prinsip berusaha sambil berdoa. Goleman juga menambahkan kecerdasan emosional merupakan sisi lain dari kecerdasan kognitif yang berperan dalam aktivitas manusia yang meliputi kesadaran diri dan kendali dorongan hati, ketekunan, semangat dan motivasi diri serta empati dan kecakapan sosial. Kecerdasan emosional lebih ditujukan kepada upaya mengenali, memahami dan mewujudkan emosi dalam porsi yang tepat dan upaya untuk mengelola emosi agar terkendali dan dapat memanfaatkan untuk memecahkan masalah kehidupan terutama yang terkait dengan hubungan antar manusia.

Goleman dalam Setyawan $(2005 ; 126)$ menggambarkan kecerdasan emosi dalam 5 aspek kemampuan utama, yaitu:

1) Mengenali emosi diri

Mengenali emosi diri sendiri merupakan suatu kemampuan untuk mengenali perasaan sewaktu perasaan itu terjadi. Kemampuan ini merupakan dasar dari kecerdasan emosional, para ahli psikologi menyebutkan kesadaran diri sebagai metamood, yakni kesadaran seseorang akan emosinya sendiri. Menurut Goleman, kesadaran diri adalah waspada terhadap suasana hati maupun pikiran tentang suasana hati, bila kurang waspada maka individu menjadi mudah larut dalam aliran emosi dan dikuasai oleh emosi. Kesadaran diri memang belum menjamin penguasaan emosi, namun merupakan salah satu prasyarat penting untuk mengendalikan emosi sehingga individu mudah menguasai emosi.

2) Mengelola emosi

Mengelola emosi merupakan kemampuan individu dalam menangani perasaan agar dapat terungkap dengan tepat atau selaras, sehingga tercapai keseimbangan dalam diri individu. Menjaga agar emosi yang merisaukan tetap terkendali merupakan kunci menuju kesejahteraan emosi. Emosi berlebihan, yang meningkat dengan intensitas terlampau lama akan mengoyak kestabilan kita. Kemampuan ini mencakup kemampuan untuk menghibur diri sendiri, melepaskan kecemasan, kemurungan atau ketersinggungan dan akibat-akibat yang ditimbulkannya serta kemampuan untuk bangkit dari perasaan-perasaan yang menekan.

3) Memotivasi diri sendiri

Prestasi harus dilalui dengan dimilikinya motivasi dalam diri individu, yang berarti memiliki ketekunan untuk menahan diri terhadap kepuasan dan mengendalikan dorongan hati, serta mempunyai perasaan motivasi yang positif, yaitu antusianisme, gairah, optimis dan keyakinan diri.

4) Mengenali emosi orang lain

Kemampuan untuk mengenali emosi orang lain disebut juga empati. Menurut Goleman, kemampuan seseorang untuk mengenali orang lain atau peduli, menunjukkan 
kemampuan empati seseorang. Individu yang memiliki kemampuan empati lebih mampu menangkap sinyal-sinyal sosial yang tersembunyi yang mengisyaratkan apa-apa yang dibutuhkan orang lain sehingga ia lebih mampu menerima sudut pandang orang lain, peka terhadap perasaan orang lain dan lebih mampu untuk mendengarkan orang lain.

5) Membina hubungan

Kemampuan dalam membina hubungan merupakan suatu keterampilan yang menunjang popularitas, kepemimpinan dan keberhasilan antar pribadi. Keterampilan dalam berkomunikasi merupakan kemampuan dasar dalam keberhasilan membina hubungan. Individu sulit untuk mendapatkan apa yang diinginkannya dan sulit juga memahami keinginan serta kemauan orang lain. Orang-orang yang hebat dalam keterampilan membina hubungan ini akan sukses dalam bidang apapun. Orang berhasil dalam pergaulan karena mampu berkomunikasi dengan lancar pada orang lain. Orang-orang ini populer dalam lingkungannya dan menjadi teman yang menyenangkan karena kemampuannya berkomunikasi.

\section{Kinerja}

Kinerja berasal dari kata job performance atau actual performance yang berarti prestasi kerja atau prestasi sesungguhnya yang dicapai oleh seseorang. Pengertian kinerja (prestasi kerja) adalah hasil kerja secara kualitas dan kuantitas yang dicapai oleh seorang pegawai dalam melaksanakan fungsinya sesuai dengan tanggung jawab yang diberikan kepadanya.

Kinerja adalah kesediaan seseorang atau kelompok orang untuk melakukan sesuatu kegiatan dan menyempurnakan sesuai dengan tanggung jawabnya dengan hasil seperti yang diharapkan (Rivai, 2008; 15). Pendapat lainnya menyebutkan bahwa kinerja diartikan sebagai hasil dari usaha seseorang yang telah dicapainya dengan kemampuan yang telah dimilikinya pada kondisi tertentu (Mangkunegara, 2007; 65).

Menurut Robbins (2006; 260) terdapat lima indikator untuk mengukur kinerja pegawai atau karyawan secara individu, yaitu:

1) Kualitas

Kualitas kerja diukur dari persepsi karyawan terhadap kualitas pekerjaan yang dihasilkan serta kesempurnaan tugas terhadap keterampilan dan kemampuan karyawan.

2) Kuantitas

Merupakan jumlah yang dihasilkan dinyatakan dalam istilah seperti jumlah unit, jumlah siklus aktivitas yang diselesaikan.

3) Ketepatan waktu

Merupakan tingkat aktivitas diselesaikan pada awal waktu yang dinyatakan, dilihat dari sudut koordinasi dengan hasil output serta memaksimalkan waktu yang tersedia untuk aktivitas lain.

4) Efektivitas

Merupakan tingkat penggunaan sumber daya organisasi (tenaga, uang, teknologi, bahan baku) dimaksimalkan dengan maksud menaikkan hasil dari setiap unit dalam penggunaan sumber daya.

5) Kemandirian

Merupakan tingkat seorang karyawan yang nantinya akan dapat menjalankan fungsi kerjanya berdasarkan komitmen kerja. Merupakan suatu tingkat dimana karyawan mempunyai komitmen kerja dengan instansi dan tanggung jawab karyawan terhadap kantor.

\section{Hubungan Antara Hubungan Interpesonal Dengan Kinerja}

Keterkaitan antara hubungan interpersonal dengan kinerja secara tidak langsung telah terlihat melalui faktor-faktor yang mempengaruhi kinerja individual yang telah dikemukakan oleh Mathis dan Jackson $(2006$; 36) mereka menyebutkan bahwa salah satu faktor yang mempengaruhi kinerja individu adalah kemampuan individual dalam melakukan pekerjaan yang terdiri dari bakat, minat dan faktor kepribadian. Dalam hal ini hubungan interpersonal dalam bentuk komunikasi interpersonal dapat digolongkan sebagai salah satu bentuk kemampuan yang dimiliki oleh individu.

Supriyadi (2016), melakukan penelitian tentang Pengaruh Efikasi Diri dan Hubungan Interpersonal Terhadap Kinerja Karyawan Garda Depan PT. Aseli Dagadu Djokdja. Dalam hasil penelitiannya menemukan bahwa hubungan interpersonal berpengaruh positif dan signifikan terhadap kinerja karyawan garda depan PT. Aseli Dagadu Djokdja.

\section{Hubungan Antara Lingkungan Kerja Dengan Kinerja}

Menurut Nitisemito (2000; 183), lingkungan kerja adalah segala sesuatu yang ada disekitar para pekerja yang dapat mempengaruhi 
dirinya dalam menjalankan tugas-tugas yang diembankan. Definisi mengenai lingkungan kerja juga dikemukakan oleh Sedarmayanti $(2001 ; 156)$ lingkungan kerja adalah keseluruhan alat perkakas dan bahan yang dihadapi, lingkungan sekitarnya dimana seseorang bekerja, metode kerjanya, serta pengaturan kerjanya baik sebagai perseorangan maupun sebagai kelompok dapat ditarik kesimpulannya bahwa kondisi lingkungan kerja baik akan menunjang produktivitas karyawan yang pada akhirnya berdampak pada kenaikan tingkat kinerja karyawan.

\section{Hubungan Antara Kecerdasan Emosional Dengan Kinerja \\ Ginanjar Agustian (2009; 64)} Kecerdasan emosional seorang karyawan merupakan faktor penentu keberhasilan kinerja, karna dalam kecerdasan emosional seorang karyawan mampu mengendalikan segala ego dan keinginannya serta mampu memahami orang lain atau rekan kerjanya sehingga terciptanya suasana kelompok kerja yang dinamis. Membangun dan menerapkan sistem manajemen SDM berbasis kompetensi dalam kecerdasan emosional merupakan salah satu langkah penting untuk mengembangkan keunggulan kompupetitif bisnis dalam mencapai target atau tujuan perusahaan dalam upaya pemberdayaan manajemen sumber daya manusia dalam suatu perusahaan. Dengan demikian konsep kecerdasan emosi berarti memilki kesadaran diri yang memungkinkan anda untuk mengenali perasaan-perasaan dan mengelola emosi anda sendiri, dan itu melibatkan motivasi diri dan mampu untuk fokus pada sebuah tujuan daripada menuntut pemenuhan segera. Seorang pegawai dengan kecerdasan emosional yang tinggi juga mampu untuk memahami perasaan orang lain dalam menangani hubungan sehingga tercipta kinerja yang baik dalam sebuah organisasi.

\section{METODE PENELITIAN}

\section{Populasi dan Sampel}

Populasi adalah kumpulan subjek yang berada dalam sebuah objek tertentu (Nasution, 2001; 98). Dalam penelitian ini populasinya adalah jumlah seluruh pegawai Kantor Komisi Pemilihan Umum Daerah (KPUD) Kabupaten Parigi Moutong, yaitu sebanyak 59 orang yang terdiri dari Pegawai Negeri Sipil sebanyak 22 orang serta pegawai honorer sebanyak 37 orang.

Selanjutnya menurut Sugiyono (2006; 59) mengungkapkan bahwa sampel adalah sebagian dari jumlah dan karakteristik yang dimiliki oleh populasi tersebut. Untuk itu sampel yang diambil dari populasi harus betul-betul representatif (mewakili). Dalam penelitian ini teknik pengambilan sampel menggunakan teknik random sampling dengan cara Proporsional Random Sampling yaitu cara pengambilan sampel yang memperhatikan pertimbangan unsur-unsur atau kategori-kategori di dalam penelitian. Adapun metode penentuan jumlah sampel dengan menggunakan formula Slovin. Dengan demikian, dari sebanyak 59 populasi, diambil sebanyak 38 orang pegawai sebagai responden dalam penelitian ini. Masing-masing sampel dilakukan penarikan berdasarkan jumlah populasi yang tersebar di beberapa unit kerja KPUD Kabupaten Parigi Moutong yaitu PNS sebanyak 14 orang dan Pegawai Honorer 24 orang.

\section{Defenisi Operasional Variabel}

Untuk memperjelas variabel-variabel yang digunakan dalam penelitian ini, dikemukakan batasan-batasan definisi operasional yang akan digunakan sebagai bahan acuan dan dijabarkan dalam bentuk kuesioner. Variabel-variabel sebagai berikut:

1. Hubungan Interpersonal $\left(\mathrm{X}_{1}\right)$

Hubungan interpersonal adalah keseluruhan hubungan baik yang bersifat formal maupun nonformal yang dilakukan seseorang kepada orang lain dalam berbagai situasi kerja dengan tujuan untuk mengembangkan rasa bahagia dan rasa puas, serta kegiatan untuk meningkatkan dan mengembangkan hasil yang lebih produktif dan memuaskan. Adapun indikator hubungan interpersonal menurut Effendy (2008; 12), adalah:
a. Harga menghargai
b. Loyal dan toleran antara satu dengan yang lainnya
c. Sikap terbuka, dan
d. Adanya keakraban

2. Lingkungan Kerja $\left(\mathrm{X}_{2}\right)$

Lingkungan kerja adalah segala sesuatu yang ada di lingkungan sekitar para pekerja dan yang dapat mempengaruhi dirinya dalam menjalankan tugas-tugas yang dibebankan kepadanya. Menurut Sedarmayanti (2001; 21) faktor-faktor yang dapat mempengaruhi terbentuknya suatu kondisi lingkungan kerja yang selanjutnya dijadikan indikator lingkungan kerja adalah sebagai berikut::

a. Kondisi ruangan kerja 
b. Dekorasi ruangan kerja (Lay Out)

c. Fasilitas dan alat bantu pekerjaan

d. Keadaan udara, dan

e. Ketenangan dalam ruang kerja

3. Kecerdasan Emosional $\left(\mathrm{X}_{3}\right)$

Kecerdasan emosional adalah kemampuan merasakan, memahami dan secara efektif menerapkan daya dan kepekaan emosi sebagai sumber energi, informasi, koreksi dan pengaruh yang manusiawi. Goleman dalam Setyawan (2005; 126) menggambarkan kecerdasan emosi dalam 5 aspek kemampuan utama, yaitu:

a. Mengenali emosi diri

b. Mengelola emosi

c. Memotivasi diri sendiri

d. Mengenali emosi orang lain

e. Membina hubungan

4. $\quad \operatorname{Kinerja~(Y)}$

Kinerja merupakan hasil upaya individu atau organisasi dalam melaksanakan kewajiban job description yang telah ditetapkan guna tercapainya hasil dari tujuan yang diberikan organisasi kepada setiap angggota organisasinya. Menurut Robbins (2006; 260) terdapat lima indikator untuk mengukur kinerja karyawan secara individu, yaitu:
a. Kualitas
b. Kuantitas.
c. Ketepatan waktu.
d. Efektivitas.
e. Kemandirian.

\section{Uji Validitas}

Menurut Santoso (2011; 268), menyatakan bahwa validitas dalam penelitian diartikan sebagai suatu derajat ketepatan alat ukur peneliti tentang isi atau arti sebenarnya yang diukur. Valid tidaknya suatu alat ukur tergantung pada kemampuan atau tidak alat ukur tersebut mencapai tujuan pengukuran yang dikehendaki. Data dikatakan valid apabila nilai probabilitas atau dalam output SPSS disebut Sig.2 tailed lebih kecil dari 5\% (level of significance) atau 0,05 nilai alpha menunjukkan bahwa pernyataan-pernyataan tersebut sudah valid. Selanjutnya apabila nilai probabilitas (Sig.2 tailed) lebih besar dari nilai alpha $=0,05$ maka item pernyataan kuesioner tersebut berstatus tidak valid atau tidak tepat dalam menjelaskan variabelnya sehingga butir tersebut dinyatakan gugur sehingga tidak digunakan dalam penelitian selanjutnya. Hasil analisis uji validitas, dinyatakan bahwa semua instrumen layak diikutsertakan dalam penelitian ini, karena nilai probabilitas atau Sig.2 tailed lebih kecil dari taraf signifikansi $(\alpha)$ 0,05 dan semua item pernyataan kuesioner berstatus valid atau tepat dalam menjelaskan variabelnya.

\section{Uji Reliabilitas}

Selain valid sebuah instrumen juga harus reliabel (dapat dipercaya). Instrumen yang reliabel adalah instrumen yang bila digunakan beberapa kali untuk mengukur objek yang sama, akan menghasilkan data yang sama. Artinya, bahwa instrumen selain harus sesuai dengan kenyataan juga harus memiliki nilai ketepatan, dimana apabila instrumen ini diberikan pada kelompok yang sama dengan waktu yang berbeda akan sama hasilnya. Pengujian reliabilitas dengan menggunakan metode Alfa Cronbach, dengan kriteria Alfa Cronbach dari masing-masing variabel > 0,60 maka alat ukur dalam penelitian ini dapat dikatakan reliable (Sugiyono, 2007; 137). Hasil uji reliabilitas menunjukkan bahwa sesungguhnya instrumen penelitian yang diajukan dalam bentuk kuesioner yang digunakan dalam penelitian ini reliabel atau andal. Hal ini disebabkan karena besarnya nilai Alpha Cronbach diatas 0.60 yang berarti memenuhi syarat minimal sebagaimana terlihat dalam tabel berikut:

Tabel 1. Hasil Uji Reliabilitas

\begin{tabular}{|l|c|c|}
\hline \multicolumn{1}{|c|}{ Variabel Penelitian } & $\begin{array}{c}\text { Alpha } \\
\text { Cronbach }\end{array}$ & Keterangan \\
\hline Hubungan Interpersonal & 0.716 & Reliabel \\
\hline Lingkungan Kerja & 0.645 & Reliabel \\
\hline Kecerdasan Emosional & 0.861 & Reliabel \\
\hline Kinerja & 0.781 & Reliabel \\
\hline
\end{tabular}

\section{Uji Asumsi Klasik}

Pengujian asumsi klasik atau di sebut asumsi regresi bertujuan mengetahui kelayakan model persamaan regresi yang dihasilkan. Jika model persamaan memenuhi asumsi tersebut maka persamaan regresi terbebas dari penyakit regresi. Beberapa asumsi klasik yaitu:

1) Uji Normalitas

Normalitas data dapat dilakukan dengan melihat probability plot (p-plot), dimana normalitas data dapat dideteksi dengan cara melihat peyebaran data (titik) pada sumbu diagonal dari grafik. Jika data menyebar di sekitar garis diagonal dan mengikuti arah garis diagonal, maka model regresi 
memenuhi asumsi normalitas dan sebaliknya (Ghozali, 2005; 91). Berikut hasil uji normalitas dengan melihat grafik p-plot.

\section{Gambar 3.1}

\section{Grafik Normal Probability-Plot}

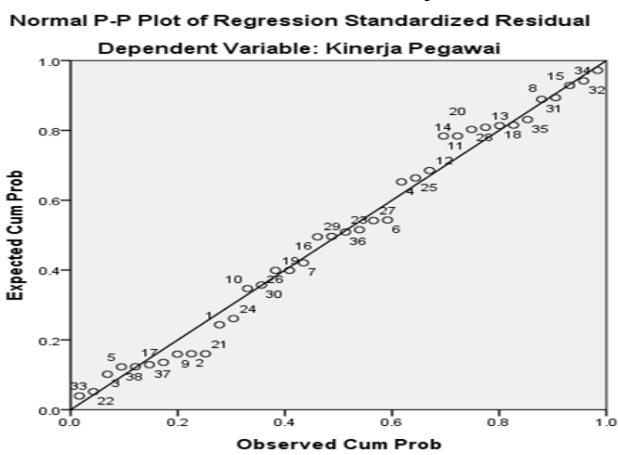

Dari Gambar 3.1 grafik Normal P-Plot di atas terlihat bahwa titik menyebar di sekitar garis diagonal, serta penyebarannya mengikuti garis diagonal maka dapat disimpulkan bahwa model regresi dalam penelitian ini memenuhi asumsi normalitas.

2) Uji Heterokedastisitas

Uji asumsi heterokedastisitas dimaksudkan untuk mengetahui apakah dalam model regresi linear berganda terjadi ketidaksamaan varians terhadap residual dari satu pengamatan ke pengamatan yang lain (Santoso, 2011; 210). Dasar keputusan menyangkut asumsi heterokedastisitas didasarkan pada grafik heterokedastisitas dengan keputusan yaitu jika ada pola tertentu, seperti titik-titik (poin-poin) yang ada membentuk suatu pola tertentu yang teratur (bergelombang, melebar kemudian menyempit), maka telah terjadi heterokedastisitas. Namun jika tidak ada pola yang jelas, serta titik-titik menyebar di atas dan dibawah angka nol pada sumbu Y, maka tidak terjadi heterokedastisitas. Model regresi yang baik menurut Santoso adalah bebas dari masalah heterokedastisitas. Hasil analisis uji heteroskedastisitas ditunjukkan dalam grafik berikut:

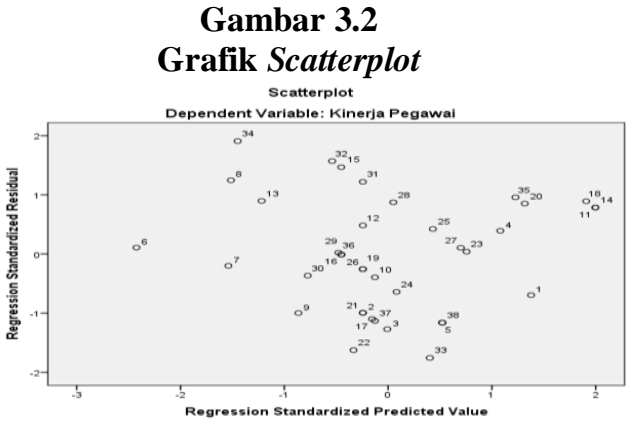

Dari grafik Scatterplot diatas menunjukkan bahwa nilai-nilai sebaran data penelitian tersebar secara acak, tidak membentuk suatu pola tertentu yang jelas, tersebar baik diatas maupun dibawah angka nol pada sumbu Y. Hal ini berarti tidak terjadi heterokedastisitas pada model regresi, sehingga model regresi layak digunakan.

3) Uji Multikolinearitas

Multikolinearitas adalah keadaan dimana pada model regresi ditemukan adanya korelasi yang sempurna atau mendekati sempurna antar variabel independen (Priyatno, 2012; 151). Uji Multikolinearitas dapat dilakukan dengan melihat nilai Tolerance dan Variance Inflation Factor (VIF). Jika nilai tolerance lebih besar dari 0,1 atau nilai VIF lebih kecil dari 10 , maka model regresi dinyatakan tidak terdapat gejala multikolinear (Ghozali, 2005; 91). Berdasarkan hasil output SPSS, dapat dilihat hasil uji multikolinearitas untuk masingmasing variabel independen pada tabel dibawah berikut:

Tabel 2. Hasil Uji Multikolinearitas Coefficients $^{a}$

\begin{tabular}{|l|r|c|}
\hline \multirow{2}{*}{\multicolumn{1}{|c|}{ Model }} & \multicolumn{2}{c|}{ Collinearity Statistics } \\
\cline { 2 - 3 } & Tolerance & \multicolumn{1}{c|}{ VIF } \\
\hline (Constant) & & \\
Hubungan Interpersonal & .741 & 1.350 \\
Lingkungan Kerja & .717 & 1.395 \\
Kecerdasan Emosional & .944 & 1.059 \\
\hline
\end{tabular}

Dari nilai pada tabel 3.4 diatas dapat dilihat nilai Tolerance seluruh variabel independen lebih besar dari 0,10, yang berarti tidak ada korelasi antar variabel independen. Hasil perhitungan nilai Variance Inflation Factor (VIF) juga menunjukan hal yang sama, 
seluruh variabel independen memiliki nilai VIF di bawah dari angka 10, maka dapat dikatakan bebas dari gejala multikolinearitas. Dengan demikian dapat disimpulkan bahwa tidak ada multikolinearitas antar variabel independen dalam model regresi.

\section{HASIL DAN PEMBAHASAN} Hasil Uji Regresi

Analisis regresi linier berganda digunakan untuk mengetahui seberapa besar pengaruh faktor yang digunakan dalam model penelitian yaitu hubungan interpersonal, lingkungan kerja dan kecerdasan emosional terhadap kinerja pegawai. Berdasarkan hasil olah data statistik yang telah dianalisis diperoleh hasil sebagai berikut:

Tabel 3. Hasil Uji Regresi Linear Berganda

Coefficients $^{a}$

\begin{tabular}{|l|c|c|c|r|r|}
\hline \multirow{3}{*}{ Model } & \multicolumn{2}{|c|}{$\begin{array}{c}\text { Unstandardized } \\
\text { Coefficients }\end{array}$} & $\begin{array}{c}\text { Standardized } \\
\text { Coefficients }\end{array}$ & \multirow{2}{*}{$\mathrm{t}$} & \multirow{2}{*}{ Sig. } \\
\cline { 2 - 5 } & $\mathrm{B}$ & $\begin{array}{c}\text { Std. } \\
\text { Error }\end{array}$ & Beta & & \\
\hline (Constant) & .331 & .635 & & .522 & .604 \\
X1 & .428 & .099 & .465 & 4.348 & .000 \\
X2 & .398 & .102 & .426 & 3.922 & .000 \\
X3 & .094 & .094 & .094 & .992 & .326 \\
\hline
\end{tabular}

Dari nilai-nilai yang ditunjukkan pada tabel di atas, diperoleh persamaan model regresi sebagai berikut:

$$
\mathrm{Y}=0.331+0.428 \mathrm{X}_{1}+0.398 \mathrm{X}_{2}+0.094 \mathrm{X}_{3}+\mathrm{e}
$$

Persamaan regresi diatas memberikan gambaran mengenai besarnya pengaruh variabel bebas terhadap variabel terikat. Dimana dari koefisien $\mathrm{X}_{1}$ (Hubungan Interpersonal), $\mathrm{X}_{2}$ (Lingkungan Kerja), dan $X_{3} \quad$ (Kecerdasan Emosional) yang bertanda positif (+) menunjukkan bahwa terdapat pengaruh positif yang searah antara variabel bebas $\left(\mathrm{X}_{1}, \mathrm{X}_{2}\right.$ dan $\left.\mathrm{X}_{3}\right)$ dengan variabel terikat $(\mathrm{Y})$. Persamaan regresi diatas dapat pula dijelaskan sebagai berikut:

a) Konstanta sebesar 0,331, artinya jika Hubungan Interpersonal $\left(\mathrm{X}_{1}\right)$, Lingkungan Kerja $\left(\mathrm{X}_{2}\right)$, dan Kecerdasan Emosional $\left(\mathrm{X}_{3}\right)$ adalah 0 , maka Kinerja (Y) nilainya adalah 0,331 .

b) Koefisien regresi variabel Hubungan Interpersonal $\left(\mathrm{X}_{1}\right)$ sebesar 0,428 , artinya jika Hubungan Interpersonal mengalami kenaikan 1\%, maka Kinerja (Y) akan mengalami peningkatan sebesar 0,428 . c) Koefisien regresi variabel Lingkungan Kerja $\left(\mathrm{X}_{2}\right)$ sebesar 0,398, artinya jika Lingkungan Kerja mengalami kenaikan $1 \%$, maka Kinerja (Y) akan mengalami peningkatan sebesar 0,398.

d) Koefisien regresi variabel Kecerdasan Emosional $\left(\mathrm{X}_{3}\right)$ sebesar 0,094, artinya jika Kecerdasan Emosional mengalami kenaikan 1\%, maka Kinerja (Y) akan mengalami peningkatan sebesar 0,094 .

\section{Hasil Uji Hipotesis Pertama}

Hipotesis pertama dalam penelitian ini menyatakan bahwa hubungan interpersonal, lingkungan kerja dan kecerdasan emosional secara serempak berpengaruh signifikan terhadap kinerja pegawai KPUD Kabupaten Parigi Moutong. Pengujian hipotesis pertama dianalisis dengan menggunakan analisis regresi linier berganda.

Uji kelayakan model akan dianalisa dengan membandingkan nilai probabilitas pada output Uji-F dengan level of significant 5\%. Kriteria pengambilan keputusan adalah Jika nilai signifikansi $<$ nilai $\alpha=0,05$ maka variabel bebas berpengaruh signifikan terhadap variabel terikat. Jika nilai signifikansi $>$ nilai $\alpha=0,05$ maka variabel bebas tidak berpengaruh signifikan terhadap variabel terikat. Output uji kelayakan model (uji F) disajikan pada Tabel 4, sebagai berikut:

Tabel 4. Hasil Uji Serempak (Uji-F)

\begin{tabular}{|l|c|c|c|c|c|}
\hline \multicolumn{1}{|c|}{ Model } & $\begin{array}{c}\text { Sum of } \\
\text { Squares }\end{array}$ & Df & $\begin{array}{c}\text { Mean } \\
\text { Square }\end{array}$ & F & Sig. \\
\hline Regression & 3.799 & 3 & 1.266 & 17.255 & $.000^{\mathrm{b}}$ \\
Residual & 2.495 & 34 & .073 & & \\
Total & 6.295 & 37 & & & \\
\hline
\end{tabular}

Hasil perhitungan pada Tabel 4 diatas, menunjukkan bahwa nilai signifikansi sebesar 0,000 lebih kecil dari nilai $\alpha=0,05$. Ini berarti bahwa variabel hubungan interpersonal, lingkungan kerja dan kecerdasan emosional berpengaruh secara serempak terhadap kinerja pegawai KPUD Kabupaten Parigi Moutong. Dengan demikian hipotesis pertama yang diajukan dalam penelitian ini dapat diterima dan terbukti kebenarannya. 


\section{Hasil Uji Hipotesis Kedua}

Hipotesis kedua dalam penelitian ini menyatakan bahwa hubungan interpersonal berpengaruh positif dan signifikan terhadap kinerja pegawai KPUD Kabupaten Parigi Moutong. Pengujian hipotesis kedua ini dianalisis dengan menggunakan analisis regresi linier berganda. Uji kelayakan model akan dianalisa dengan membandingkan nilai probabilitas pada output Uji-t dengan level of significant $5 \%$. Penerimaan atau penolakan hipotesis dilakukan dengan kriteria jika nilai signifikansi $>$ nilai $\alpha=$ 0,05 maka hipotesis ditolak. Jika nilai signifikansi $<$ nilai $\alpha=0,05$ maka hipotesis diterima. Hasil pengujian regresi linear berganda sebagaimana Tabel.3 diatas, menunjukkan bahwa nilai signifikansi variabel hubungan interpersonal sebesar 0,000 lebih kecil dari nilai $\alpha=0,05$. Ini membuktikan bahwa secara parsial variabel hubungan interpersonal berpengaruh signifikan terhadap kinerja pegawai KPUD Kabupaten Parigi Moutong. Dengan demikian hipotesis kedua dalam penelitian ini diterima dan terbukti kebenarannya.

\section{Hasil Uji Hipotesis Ketiga}

Hipotesis ketiga dalam penelitian ini menyatakan bahwa lingkungan kerja berpengaruh positif dan signifikan terhadap kinerja pegawai KPUD Kabupaten Parigi Moutong. Pengujian hipotesis ketiga ini dianalisis dengan menggunakan analisis regresi linier berganda. Uji kelayakan model akan dianalisa dengan membandingkan nilai probabilitas pada output Uji-t dengan level of significant 5\%. Penerimaan atau penolakan hipotesis dilakukan dengan kriteria jika nilai signifikansi $>$ nilai $\alpha=0,05$ maka hipotesis ditolak. Jika nilai signifikansi $<$ nilai $\alpha=$ 0,05 maka hipotesis diterima. Hasil pengujian regresi linear berganda sebagaimana Tabel.3 diatas, menunjukkan bahwa nilai signifikansi variabel lingkungan kerja sebesar 0,000 lebih kecil dari nilai $\alpha=0,05$. Ini membuktikan bahwa secara parsial variabel lingkungan kerja berpengaruh signifikan terhadap kinerja pegawai KPUD Kabupaten Parigi Moutong. Dengan demikian hipotesis ketiga dalam penelitian ini diterima dan terbukti kebenarannya.

\section{Hasil Uji Hipotesis Keempat}

Hipotesis keempat dalam penelitian ini menyatakan bahwa kecerdasan emosional berpengaruh signifikan terhadap kinerja pegawai
KPUD Kabupaten Parigi Moutong. Pengujian hipotesis keempat ini dianalisis dengan menggunakan analisis regresi linier berganda. Uji kelayakan model akan dianalisa dengan membandingkan nilai probabilitas pada output Uji-t dengan level of significant 5\%. Penerimaan atau penolakan hipotesis dilakukan dengan kriteria jika nilai signifikansi $>$ nilai $\alpha=0,05$ maka hipotesis ditolak. Jika nilai signifikansi $<$ nilai $\alpha=$ 0,05 maka hipotesis diterima. Hasil pengujian regresi linear berganda sebagaimana Tabel.3 diatas, menunjukkan bahwa nilai signifikansi variabel kecerdasan emosional sebesar 0,326 lebih kecil dari nilai $\alpha=0,05$. Ini membuktikan bahwa secara parsial variabel kecerdasan emosional tidak berpengaruh signifikan terhadap kinerja pegawai KPUD Kabupaten Parigi Moutong. Dengan demikian hipotesis keempat dalam penelitian ini ditolak dan tidak terbukti kebenarannya.

\section{Pembahasan}

Hipotesis dalam penelitian ini menyatakan bahwa hubungan interpersonal, lingkungan kerja dan kecerdasan emosional secara serempak berpengaruh positif dan signifikan terhadap kinerja pegawai Kantor Komisi Pemilihan Umum Daerah (KPUD) Kabupaten Parigi Moutong. Berdasarkan hasil uji regresi linier berganda, hipotesis dalam penelitian ini terbukti kebenarannya. Berdasarkan hasil uji parsial ditemukan bahwa kedua variabel bebas yaitu hubungan interpersonal dan lingkungan kerja berpengaruh signifikan terhadap kinerja pegawai Kantor Komisi Pemilihan Umum Daerah (KPUD) Kabupaten Parigi Moutong, sedangkan salah satu variabel bebas yaitu kecerdasan emosional tidak berpengaruh signifikan terhadap kinerja pegawai Kantor Komisi Pemilihan Umum Daerah (KPUD) Kabupaten Parigi Moutong.

Hubungan Interpersonal adalah interaksi antara seseorang dengan orang lain dalam situasi kerja dan dalam organisasi sebagai motivasi untuk bekerja sama secara produktif. Saat seseorang tidak merasa senang dengan situasi kerjanya biasanya mereka mengatakan bahwa tidak puas dalam pekerjaannya. Ada dua hal yang mungkin menyebabkan hal itu, hal pertama apabila orang tersebut tidak mendapatkan informasi yang dibutuhkan untuk melaksanakan pekerjaannya. Yang kedua, apabila hubungan sesama teman kerja kurang baik dalam menjalin hubungan atau pun menjalin komunikasi. Berdasarkan pengujian hipotesis yang dilakukan menunjukkan bahwa ada 
pengaruh positif dan signifikan antara hubungan interpersonal dan kinerja. Hal ini berarti hipotesis kedua diterima yang mengandung arti bahwa semakin tinggi hubungan interpersonal semakin tinggi pula kinerja pegawai. Hubungan positif yang signifikan yang terjadi antara hubungan interpersonal dan kinerja dalam penelitian ini sesuai dengan penelitian Vemmylia (2009) dan Supriyadi (2016) yang diperoleh nilai signifikansi variabel hubungan interpersonal adalah 0,000 lebih kecil dari nilai alpha $(\alpha)=0,05$, yang berarti dapat disimpulkan variabel hubungan interpersonal secara parsial berpengaruh positif dan signifikan terhadap variabel terikat kinerja. Hal ini berarti faktor hubungan interpersonal yang terdiri dari saling menghargai, loyal dan toleran antara satu dengan yang lainnya, sikap terbuka, adanya keakraban yang ada dalam organisasi sudah cukup baik karena mampu meningkatkan kinerja pegawai sehingga dapat meningkatkan hasil kerja pegawai.

Lingkungan kerja adalah segala sesuatu yang ada disekitar para pekerja dan dapat mempengaruhi dalam menjalankan tugas-tugas yang dibebankan. Pegawai selalu menuntut adanya lingkungan tempat mereka bekerja lebih nyaman sehingga optimalisasi kerja pegawai dapat tercapai dengan baik. Pegawai tidak akan bekerja secara optimal apabila kondisi lingkungan tempat ia bekerja seperti penerangan tidak terpenuhi, suara gaduh, suhu udara terlalu lembab dan panas. Selain itu juga perlu diperhatikan tata ruang yaitu penentuan mengenai kebutuhan-kebutuhan ruang, tentang penggunaan secara terperinci dari ruang ini untuk menyiapkan suara susunan yang praktis dari faktor fisik yang dianggap perlu pelaksanaan kerja perkantoran yang layak. Berdasarkan hasil analisis dan uji hipotesis, hasil perhitungan terhadap koefisien menunjukkan ada pengaruh positif dan signifikan antara lingkungan kerja terhadap kinerja pegawai, artinya hipotesi yang diajukan dalam penelitian ini diterima. Berarti variabel lingkungan kerja berpengaruh dan signifikan terhadap kinerja pegawai. Hubungan positif dan signifikan antara lingkungan kerja terhadap kinerja pada penelitian ini sesuai pula dengan penelitian Rumondang Sialagan (2015) yang diperoleh nilai signifikansi variabel lingkungan kerja sebesar 0,000 lebih kecil dari nilai alpha 0,05 yang berarti dapat disimpulkan bahwa variabel lingkungan kerja secara parsial berpengaruh signifikan terhadap kinerja. Hal ini berarti lingkungan kerja yang terdiri dari penerangan, warna yang sesuai, kebersihan serta keamanan dapat meningkatkan kegairahan kerja pada pegawai yang bermanfaat bagi institusi dalam menyelengarakan penyelesaian pekerjaan. Keadaan lingkungan yang nyaman sesungguhnya berpengaruh dalam mengurangi rasa cepat lelah serta menghilangkan atau mengurangi rasa bosan sehingga semangat kerja meningkat, betah ditempat kerja dan bertanggung jawab dalam melaksanakan tugasnya dan pada akhirnya terpuaskan sehingga tercipta kinerja yang baik dan maksimal. Semakin karyawan/pegawai dapat secara langsung merasakan kenyamanan ditempat kerjanya maka hasil pekerjaan yang memuaskan akan dapat pula dirasakan oleh instansi dimana mereka bekerja.

Dari hasil penelitian ini ditemukan bahwa variabel kecerdasan emosional tidak berpengaruh signfikan terhadap kinerja pegawai. Hasil ini bertolak belakang dan tidak sesuai dengan penelitian yang dilakukan oleh Vemmylia (2009), yang dalam penelitiannya menyebutkan terdapat pengaruh yang signifikan antara kecerdasan emosional terhadap kinerja pegawai.

\section{KESIMPULAN DAN SARAN Kesimpulan}

Berdasarkan hasil pembahasan sebelumnya, maka dapat ditarik kesimpulan sebagai berikut:

1. Hubungan interpersonal, lingkungan kerja dan kecerdasan emosional secara serempak berpengaruh positif dan signifikan terhadap kinerja pegawai Kantor Komisi Pemilihan Umum Daerah (KPUD) Kabupaten Parigi Moutong.

2. Hubungan interpersonal berpengaruh signifikan terhadap kinerja pegawai Kantor Komisi Pemilihan Umum Daerah (KPUD) Kabupaten Parigi Moutong.

3. Lingkungan kerja berpengaruh terhadap kinerja pegawai Kantor Komisi Pemilihan Umum Daerah (KPUD) Kabupaten Parigi Moutong.

4. Kecerdasan emosional tidak berpengaruh signifikan terhadap kinerja pegawai Kantor Komisi Pemilihan Umum Daerah (KPUD) Kabupaten Parigi Moutong.

\section{Saran}

Berdasarkan hasil pembahasan dalam penelitian ini, serta pengetahuan dan pengalaman 
yang peneliti dapatkan selama proses penelitian, maka dikemukakan saran-saran sebagai berikut:

1. Penelitian selanjutnya hendaknya memperluas sampel penelitian, tidak hanya pada pegawai KPUD Kabupaten Parigi Moutong saja, tetapi dapat mengambil sampel dari perusahaan dagang/jasa atau kantor dinas dan instansi pemerintah yang lain. Serta dapat menambahkan atau menggunakan variabel-variabel lain yang dapat mempengaruhi kinerja. Hal ini karena masih ada variabel lain yang belum diteliti oleh penulis terkait kinerja.

2. KPUD Kabupaten Parigi Moutong kiranya dapat meningkatkan aspek-aspek yang menunjang dalam lingkungan kerja serta faktor lain diluar hubungan interpersonal, lingkungan kerja dan kecerdasan emosional untuk meningkatkan kinerja pegawainya.

3. Hasil uji statistik menunjukkan faktor kecerdasan emosional tidak berpengaruh terhadap kinerja pegawai. Dengan dasar tersebut diharapkan pihak Manajemen SDM KPUD Kabupaten Parigi Moutong dapat memberikan nilai tambah dalam bentuk pelatihan dan penguatan SDM terhadap pegawainya, agar tercipta kecerdasan emosional yang baik kepada pegawainya sehingga terwujud kinerja yang baik dan maksimal.

\section{DAFTAR PUSTAKA}

Arifin, Johar. 2007. Seri Solusi Manajemen dan Bisnis Berbasis TI. Jakarta: Elex Media Komputindo

Davis, Keith dan Newstrom. J. W. 1996. Perilaku dalam Organisasi Jilid 2 (Terjemahan) Jakarta: Erlangga.

Effendy. 2008. Psikologi Manajemen \& Administrasi. Bandung: Mandar Maju

Fathoni. 2006. Manajemen Sumber Daya Manusia. Bandung: Rineka

George, Terry. 2003. Prinsip-prinsip Management. Jakarta: PT. Bumi Aksara

Ghozali, Imam. 2005. Aplikasi Analisis Multivariate dengan program SPSS. Semarang: Badan Penerbit Universitas Diponegoro

Handoko, T. Hani. 2002. Manajemen Sumber Daya Manusia.Yogyakarta: BPFE

Hasibuan, Malayu S.P. 2003. Manajemen Sumber Daya Manusia, Edisi Revisi. Jakarta: Bumi Aksara
Hasibuan, Malayu S.P. 2009. Manajemen: Dasar, Pengertian, dan Masalah. Edisi Revisi. Jakarta: Bumi Aksara

Nasution. 2001. Teknik Penarikan Sampel dan Penyusunan Skala. Bandung: Program Pascasarjana Universitas Pajajaran

Nitisemito. 2000. Manajemen Suatu Dasar dan Pengantar. Jakarta: Ghalia Indonesia

Rakhmat, Jalaludin. 2005. Psikologi Komunikasi. Bandung: PT. Raya Media

Riduwan. 2003. Dasar-Dasar Statistika, Cetakan Ketiga, Bandung: Alfabeta

Rivai, Veithzal. 2006. Manajemen Sumber Daya Manusia Untuk Perusahaan. Jakarta: Raja Grafindo Persada

Robbins, S.P. 2002. Perilaku Organisasi. Buku 2, Jakarta: Salemba Empat

Robbins, S.P. 2006. Perilaku Organisasi, Edisi kesepuluh. Jakarta: PT Indeks

Santoso, Singgih. 2011. Mengatasi Berbagai Masalah Statistik dengan SPSS versi 11.5. Jakarta: PT. Elex Komputindo

Saydam. 1996. Manajemen Sumber Daya Manusia. Jakarta: Djambatan

Sedarmayanti. 2001. Sumber Daya Manusia dan Produktivitas Kerja. Bandung: Mandar Maju

Setyawan, Jhony. 2005. Sistem Perencanaan dan Pengendalian Manajemen, Sistem Pelipatganda, Kinerja Perusahaan. Jakarta: Rineka Cipta

Siagian, P. Sondang. 2000. Fungsi-fungsi Manajerial. Jakarta: Bumi Aksara

Sialagan, Rumondang. 2015. Pengaruh Lingkungan Kerja dan Stres Kerja Terhadap Kinerja Karyawan pada PTPN VII (PERSERO) Unit Usaha Pematang Siantar. Skripsi. Tidak Dipublikasikan

Singarimbun, Masri dan Sofian Effendi. 2000. Metode Penelitian Survei. Jakarta: LP3ES

Sugiyono. 2007. Metode Penelitian Kuantitatif Kualitatif dan $R \& D$. Bandung: Alfabeta

Sunarto. 2004. Perilaku Organisasi. Yogyakarta: AMUS

Supriyadi. 2016. Pengaruh Efikasi Diri dan Hubungan Interpersonal Terhadap Kinerja Karyawan Garda Depan PT. Aseli Dagadu Djokdja. Skripsi. Tidak Dipublikasikan

Vemmylia. 2009. Pengaruh Hubungan Interpersonal dan Lingkungan Kerja Terhadap Kinerja Karyawan Pada PT. PLN Cabang Binjai. Skripsi. Tidak Dipublikasikan. 